\title{
Worldwide Usage of International Classification of Primary Care
}

\author{
Utilização da Classificação Internacional em Atenção Primária no mundo \\ El uso de la Clasificación Internacional de la Atención Primaria en el mundo
}

Nuno Basílio. Unidade de Saúde Familiar (USF) Carcavelos, Agrupamento de Centros de Saúde (ACeS) Cascais. Cascais, Distrito de Lisboa, Portugal. nunomdbasilio@gmail.com (Autor correspondente)

Carla Ramos. Unidade de Saúde Familiar (USF) S. Julião, Agrupamento de Centros de Saúde (ACeS) Lisboa Ocidental e Oeiras. Oeiras, Portugal. carlasof.ramos@gmail.com

Sofia Figueira. Unidade de Saúde Familiar (USF) S. Julião, Agrupamento de Centros de Saúde (ACeS) Lisboa Ocidental e Oeiras. Oeiras, Portugal. anasofiafigueira@gmail.com

Daniel Pinto. Unidade de Saúde Familiar (USF) S. Julião, Agrupamento de Centros de Saúde (ACeS) Lisboa Ocidental e Oeiras; Departamento de Medicina Geral e Familiar na NOVA Medical School, Universidade Nova de Lisboa. Oeiras, Portugal. danieljllpinto@gmail.com

\begin{abstract}
Objectives: To describe the worldwide use of the International Classification of Primary Care (ICPC) and other classifications in primary care settings and to identify details of ICPC use in each country. Methods: A research survey with a questionnaire requiring self-completion was emailed to members of the WONCA International Classification Committee (WICC) and family physicians (FP) from each country recognized by the United Nations (UN). Results: We obtained the e-mail addresses of representatives from 109 countries and received 61 responses (out of 259 requests sent) to the questionnaire from 52 different countries; 30 were obtained from Europe, 8 from Asia, 7 from America, 6 from Africa, and 1 from Oceania. In 34 countries (17\%), a version of ICPC was available in a national language. ICPC was used in primary care setting in 27 countries (14\%), but it was a mandatory standard in only $6(3 \%)$. Assessment of the topics accounted for in the clinical records showed that 10 countries used ICPC to classify the patient's reasons for encounter and diagnosis, while just 5 countries used ICPC to classify the patient's reasons for encounter, diagnosis, and processes of care. Of the 24 countries responding that the use of ICPC for clinical records was not promoted in primary care, 19 used the $10^{\text {th }}$ edition of the International Classification of Diseases (ICD), 3 used other classifications, and 2 did not use any classification. Conclusions: Although the response rate to the questionnaire was low, we concluded that ICPC use is not widespread globally. Even for those countries reporting the use of ICPC in primary care, it is usually not a mandatory standard.
\end{abstract}

Keywords: International Classification of Primary Care Primary Health Care Health Classifications International Classification of Diseases Medical Records
Como citar: Basílio N, Ramos C, Figueira S, Pinto D. Worldwide Usage of International Classification of Primary Care use. Rev Bras Med Fam Comunidade. 2016;11(38):1-9. http://dx.doi.org/10.5712/rbmfc11(38)1225
Fonte de financiamento: declaram não haver. Parecer CEP: não se aplica. Conflito de interesses: declaram não haver. Procedência e revisão por pares: revisado por pares. Recebido em: 13/10/2015. Aprovado em: 26/01/2016. 


\section{Resumo}

Objetivo: Caracterizar a utilização mundial da Classificação Internacional em Atenção Primária (CIAP) e outras classificações de saúde ao nível da Atenção Primária à Saúde (APS) e identificar especificidades de utilização em cada país. Métodos: Questionário de autopreenchimento enviado a membros do Comitê Internacional de Classificações da WONCA (WICC) e médicos de família de cada um dos países reconhecidos como tal pela Organização das Nações Unidas (ONU). Resultados: Obtiveram-se contatos de e-mail de representantes de 109 países e foram recebidas 61 respostas (de 259 pedidos de colaboração enviados) de 52 diferentes países: 30 da Europa, 8 da Ásia, 7 da América, 6 de África e um da Oceania. Em 34 países (17\%), há uma versão da CIAP disponível na língua nacional. A CIAP é usada na APS em 27 países (14\%), mas é obrigatória em apenas 6 (3\%). Em relação aos tópicos contabilizados nos registos clínicos, 10 países usam-na para classificar unicamente motivos de consulta e problemas e apenas 5 usam CIAP para classificar motivos de consulta, problemas e procedimentos. Em relação aos 24 países que responderam não utilizar a CIAP ao nível da APS, 19 países utilizam a Classificação Internacional de Doenças (CID) 10ª edição, 3 referem utilizar outras classificações e 2 países não utilizam qualquer classificação. Conclusões: Embora a taxa de resposta ao questionário tenha sido baixa, podemos inferir que a utilização da CIAP a nível mundial não é generalizada. Mesmo considerando os países que aplicam a CIAP na APS, a maioria não o faz de forma obrigatória.

\section{Resumen}

Objetivos: Caracterizar la utilización mundial de la Clasificación Internacional en Atención Primaria (CIAP) y otras clasificaciones al nivel de la atención primaria de salud (APS) e identificar características específicas de uso en cada país. Métodos: Cuestionario de auto-realización enviado a los miembros de la Comité Internacional de Clasificaciones de la WONCA (WICC) y a los médicos de familia de cada uno de los países reconocidos por la Organización de las Naciones Unidas (ONU). Resultados: Fueran obtenidos los contactos por correo electrónico de los representantes de 109 países y se recibió 61 respuestas al cuestionario (de 259 solicitudes enviadas) de 52 países distintos: 30 de Europa, 8 de Asia, 1 de Oceanía, 6 de África 7 de América. En 34 países (17\%) hay una versión de la CIAP que está disponible en un idioma nacional. CIAP se maneja en la atención primaria en 27 países (14\%), pero es obligatoria en solamente $6(3 \%)$. En relación a los tópicos contabilizados en los registros clínicos, 10 países utilizan la CIAP para clasificar solamente los motivos de consulta y el diagnóstico, mientras 5 la utilizan para clasificar motivos de consulta, diagnóstico y procedimientos. Cuanto a los 24 países que respondieron no utilizar la CIAP en la APS, 19 países dijeran utilizar la Clasificación Internacional de Enfermedades (CIE) 10 $10^{\mathrm{a}}$ edición, de las restantes 3 usaban otras clasificaciones y 2 ninguna clasificación. Conclusiones: Aunque la tasa de respuesta al cuestionario tenga sido baja, podemos concluir que el uso de la CIAP a nivel mundial no es generalizado. Incluso considerando los países que utilizan CIAP en atención primaria, en su mayoría no lo hacen de forma obligatoria.
Palavras-chave:

Classificação Internacional de Atenção Primária Atenção Primária à Saúde Classificações de Saúde Classificação Internacional de Doenças Registros Médicos

Palabras clave: Clasificación Internacional de la Atención Primaria Atención Primaria de Salud Clasificaciones de Salud Clasificación Internacional de Enfermedades Registros Médicos

\section{Introduction}

Clinical records are essential components of health and clinical governance. The quality of information that can be generated (epidemiological data) depends on correct and widespread use of clinical coding. ${ }^{1,2}$ Until the mid-1970s, countries with primary care mostly classified morbidity data according to the International Classification of Diseases (ICD), which decreased the ability to classify many symptoms and non-disease-related conditions. Recognition that the existing classification systems did not respond to the needs of primary care led to the development of the International Classification of Health Problems in Primary Care, Reason for Encounter, and International Classification of Health Process in Primary Care. These three classifications were then consolidated in the International Classification of Primary Care (ICPC), published in 1987 by WONCA (World Organization of National Colleges, Academies and Academic Associations of General Practitioners/Family Physicians). WONCA still retains the copyright to ICPC. ${ }^{1}$

Following this publication, health professionals were provided for the first time with the means to gather three important elements under the same classification, these being: reasons for encounter (RFE), diagnoses (D), and processes of care (PC). This allowed practitioners to record all important steps of patient primary care..$^{1,3}$ 
ICPC has gradually received worldwide recognition as an appropriate classification for family medicine and primary care, and has been intensively used in some parts of the world. It has been translated into 19 languages, and published as a book in some of these, thus allowing professionals to use a common international language. ICPC's second edition was later developed in order to achieve two main goals: to establish a connection with ICD-10, published by the WHO (World Health Organization) in 1992, and to add criteria for inclusion and cross-references for most of the items. There is a forthcoming edition (ICPC-3), which preserves the previous classification's basic structure and also includes improvements regarding the accuracy of definitions. ${ }^{1,4}$

Information on the use of clinical classifications around the world, including ICPC, has not been systematically updated over past years. The last survey concerning ICPC use around the world was a brief report about ICPC-2 published in 2003, with no described methodology, and involving only 21 countries. ${ }^{5}$ Since then, many changes have occurred in primary health care worldwide, including modifications aiming at improving postgraduate training and research in a community setting. ${ }^{6}$ Additionally, healthcare classifications are constantly evolving and being upgraded to meet the specific requirements of primary care clinical practice. Despite this worldwide effort, the practice of family medicine is not yet well established or standardized, especially in many developing countries. ${ }^{7}$

Considering these facts, the aim of this study was to provide an update regarding the current use of ICPC. This study aimed to describe the worldwide use of ICPC and other classifications in primary care settings and to identify details of ICPC use in each UN country.

\section{Methods}

\section{Selection of study subjects}

The study methodology was designed to gather a sample of participants that included at least one subject from each of the 193 countries listed on the UN website. ${ }^{8}$ In order to minimize errors, the authors preferably selected participants that were members of the $\mathrm{WICC}^{9}$ or representatives/members of a national primary care organization. Email addresses of potential participants were collected by consulting these organization's websites ${ }^{10}$ or were personally gathered during the $19^{\text {th }}$ WONCA Europe Conference held in Lisbon. Some additional contacts were kindly provided by participants who had already answered the study questionnaire. In total, valid email addresses for 259 eligible participants from 109 countries were collected.

Data collection and analysis

A questionnaire designed for self-completion was developed by the authors and was reviewed by a number of experts in order to assure its validity. The finalized questionnaire was then sent via email to all the selected participants. The questionnaire included nine different questions (eight multiple choice questions and one open response question). The participants were asked to indicate their country and region of work, and were also invited (in an optional field) to share their names and personal contact details in order to be provided with the study results. 
A list of the questions included in the questionnaire and the closed-set answers available for each question are presented, in the order of presentation, in Table 1.

Table 1. Questionnaire for the assessment of the International Classification of Primary Care worldwide.

\begin{tabular}{|c|c|}
\hline Questions & Answers available \\
\hline 1. Is there a version of ICPC available in your country's language? & Yes/No/l don’t know \\
\hline $\begin{array}{l}\text { 1.1. If your answer was yes, is the version used in conformity with } \\
\text { linguistic specifications of your country? E.g. consider the difference } \\
\text { between American English/British English/Australian English }\end{array}$ & Yes/No \\
\hline $\begin{array}{l}\text { 2. Are there any organizations/institutions in your country that own the } \\
\text { ICPC official license? }\end{array}$ & Yes/No/l don't know \\
\hline 3. Is ICPC usually used in primary care in your country/region? & Yes/No \\
\hline 3.1. If your answer was yes, how do you apply the classification? & For encounters/For episodes/Both \\
\hline 3.2. Which of the following topics are accounted for in clinical records? & Reasons for encounter/diagnosis/processes of care \\
\hline 3.3. How widespread is ICPC use? & $\begin{array}{l}\text { Official classification/Generally used by family physicians } \\
\text { but not mandatory/Some family physicians/Electronic } \\
\text { health records/Researchers and academics only }\end{array}$ \\
\hline $\begin{array}{l}\text { 4. If ICPC is not the classification adopted for clinical records in your } \\
\text { country, which of the following is used? }\end{array}$ & $\begin{array}{l}\text { ICD-10/ICD-10-CM/ICD-9/ICD-9-CM/read codes/other } \\
\text { classification/no classification }\end{array}$ \\
\hline
\end{tabular}

For questions "3.2" and "4" the participants were able to select multiple answers.

The questionnaire also included an open response question, which intended to collect the participants' personal opinion on the use of ICPC in their country.

After sending the questionnaire to all e-mail contacts, all responses were collated in a single database. There were nine cases where more than one email answer was received from each included country, and in these cases, the responses were reviewed and compared by two authors. Where data was reported differently by the two submissions, the response utilized for the study results was that obtained from the higher-level graduate doctor and/or member of WICC. Subsequent analysis of results was performed using Microsoft Excel ${ }^{\mathrm{TM}}$.

Informed consent: A brief summary of the research significance was included at the beginning of the questionnaire. Confidentiality, voluntary participation, and access to final results were guaranteed. Ethics Committee approval was not required for this study as it was an audit/survey recruiting health professionals only, and there was no collection of demographic or clinical data that might pose a risk to confidentiality or health.

\section{Results}

A total of 61 answers from 52 different countries were obtained, 2 of which were excluded because of multiple responses from the same participant. The 59 eligible responses were provided by 22 WICC members, 16 family doctors, 12 representatives of a national primary healthcare organization, and 9 academic researchers. In total, the answers were obtained from $27 \%$ of UN listed countries; 30 from Europe, 8 from Asia, 7 from America, 6 from Africa, and 1 from Oceania. Owing to the low response rate, results are presented as a proportion relative to the number of countries that responded (52) and in relation to the total number of UN-listed countries (193).

In 34 countries (65\%/18\%), a version of ICPC was available in a national language (Table 2). 
Table 2. International Classification of Primary Care distribution, version, and funding.

\begin{tabular}{|c|c|c|c|}
\hline Questions & Yes & No & I don't know \\
\hline 1. Is there a version of ICPC available in your country's language? & $34 / 52$ & $17 / 52$ & $1 / 52$ \\
\hline $\begin{array}{l}1.1 \text { If your answer was YES, is the version used in conformity with your country's linguistic } \\
\text { specifications? }\end{array}$ & $27 / 52$ & $7 / 52$ & NA \\
\hline 2. Are there any organizations/institutions in your country that own the ICPC official license? & $16 / 52$ & $25 / 52$ & $11 / 52$ \\
\hline
\end{tabular}

NA: Not applicable.

ICPC was used in primary care in 27 countries (52\%/14\%), but was reported as a mandatory standard in only $6(12 \% / 3 \%)$ (Figure 1$)$.

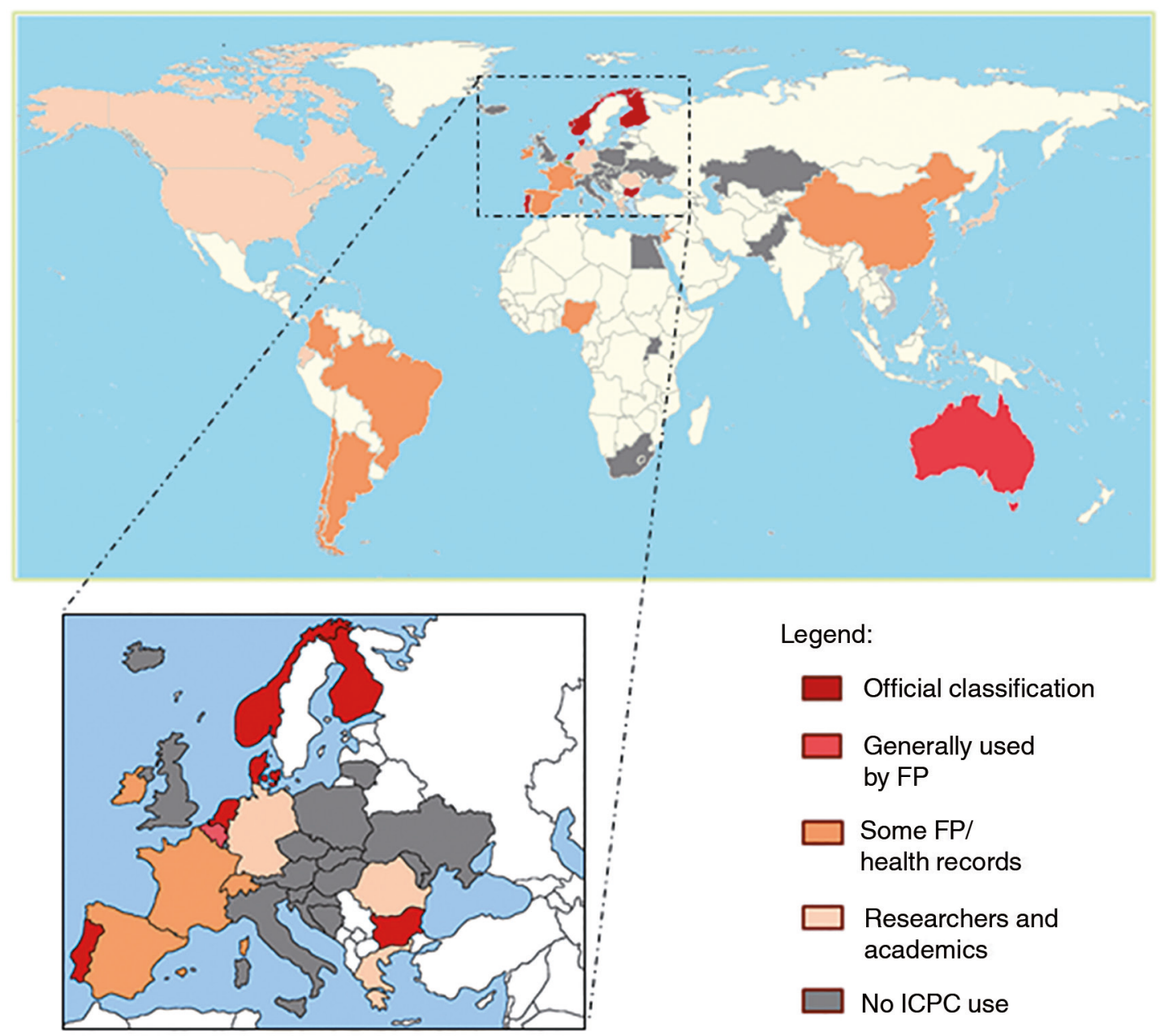

Figure 1. International Classification of Primary Care use in primary care (with magnified image of European countries).

Of the countries that reported use of ICPC in primary care, 15 used it to classify both episodes and encounters (Table 3).

Assessment of the topics accounted for in clinical records showed that 10 study participants used ICPC to classify reasons for encounter and diagnosis alone, and just 5 participants used it to classify reasons for encounter, diagnosis, and processes of care (Table 4). 
Table 3. International Classification of Primary Care clinical record applications.

\begin{tabular}{|lcccc|}
\hline Questions & For encounters & For episodes & Both & NA \\
\hline 3.1 How do you apply the classification (ICPC)? & $10 / 52$ & $3 / 52$ & $15 / 52$ & $24 / 52$ \\
\hline
\end{tabular}

NA: Not applicable.

Table 4. Topics accounted for in clinical records using the International Classification of Primary Care.

\begin{tabular}{|c|c|c|c|c|c|c|c|}
\hline Questions & Diagnosis & PC & RFE & Diagnosis + PC & Diagnosis + RFE & Diagnosis + PC + RFE & NA \\
\hline $\begin{array}{l}\text { 3.2 Which of the following topics are } \\
\text { accounted for in clinical records? }\end{array}$ & $9 / 52$ & $1 / 52$ & $2 / 52$ & $1 / 52$ & $10 / 52$ & $5 / 52$ & $24 / 52$ \\
\hline
\end{tabular}

PC: Processes of care; RFE: Reasons for encounter; NA: Not applicable.

A total of 24 countries (46\%/12\%) acknowledged that the use of ICPC for clinical records in primary care was not promoted. Of these, 19 countries used the International Classification of Diseases $10^{\text {th }}$ edition (ICD-10), 3 used other classifications, and 2 used no classification whatsoever (Figure 2).

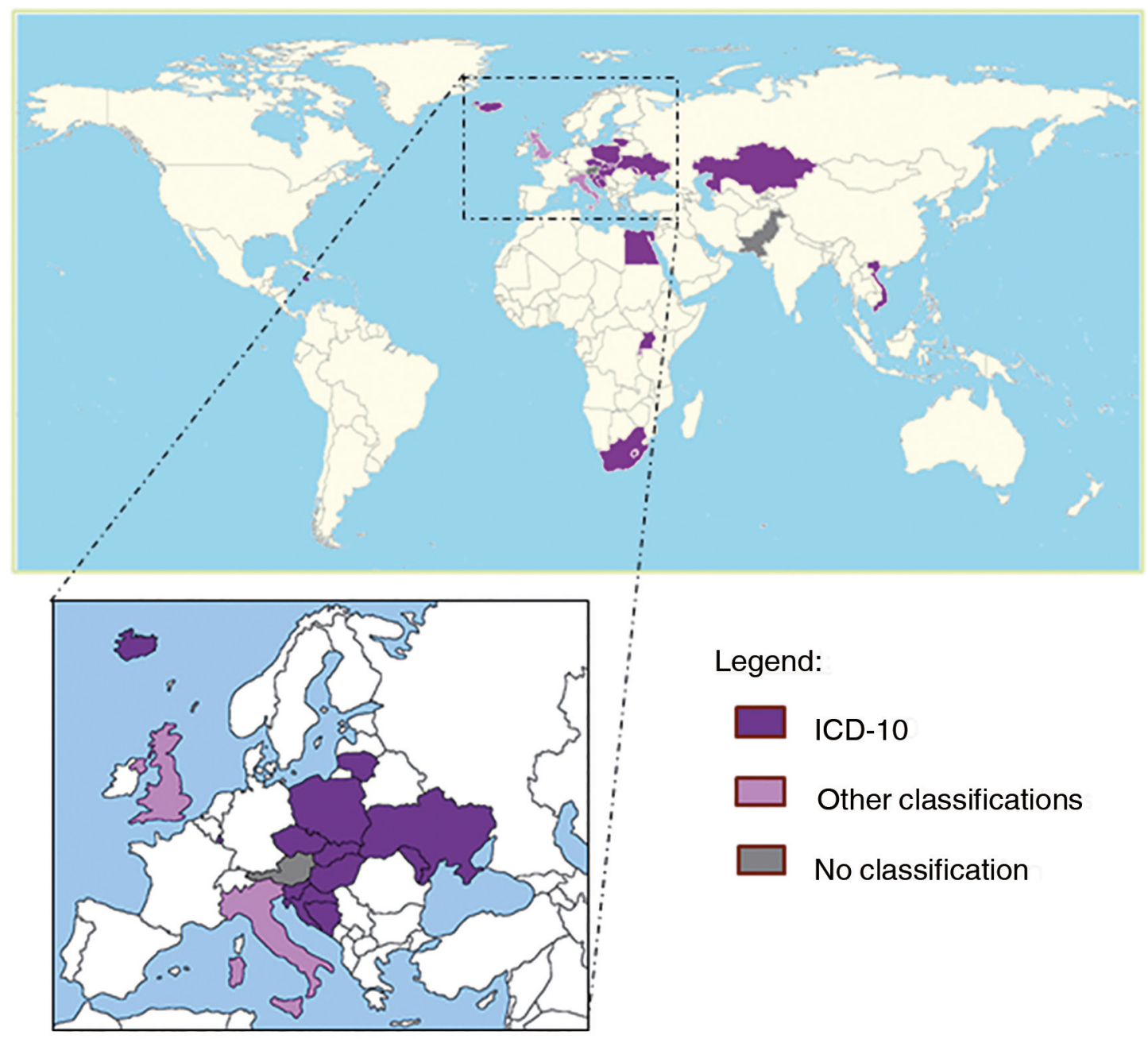

Figure 2. The distribution of other classifications when ICPC was not adopted (with a magnified box showing European countries). 


\section{Discussion}

\section{Main outcomes}

According to our results, ICPC is currently used in only a few UN countries and is mandatory in only 6 of these, with all of these located in Europe. This may be related to the requirement of a paid license for its use. The institution that holds this license may belong to public or private sector. In some cases, the institution may not have logistical/economic feasibility to establish its widespread use, as the cost is proportional to the number of users. It should also be taken into account that ICPC is available in only 19 languages, and there is often no official language reported for each country. This may influence the levels of ICPC use described in our study. Additionally, some countries lack a well-established primary care assistance program, and may therefore not have a classification system implemented. ${ }^{6,7}$

Regarding clinical records, ICPC can be used to code both encounters and episodes and, within each encounter, can be used to address RFE, diagnosis, and PC. Of the 25 countries that used ICPC for coding encounters, our study showed that only 5 used it to characterize the entire encounter (RFE + D + PC). This may be because of software limitations that only allow partial coding of the encounter. In addition, there may be countries where only some of these elements are accounted for in healthcare management and used for payment purposes.

The results from this study portray a high and unexpected adoption rate of classifications actually used in the secondary care setting, namely ICD-10. ${ }^{11}$ This may be attributable to the fact that ICD was first developed to describe mortality and morbidity, especially in public health, and therefore, almost every country in the world now has a license for the ICD. ${ }^{11} \mathrm{~A}$ generalized underdevelopment of primary care services may also be partly responsible for an undervaluation of the need for a specific classification at the level of primary care..$^{12,13}$

\section{Study strengths and weaknesses}

A notable selection bias present within our study was the absence of participants from 84 UN countries. Our study may have also been underpowered because of a low response rate, with the results from only $27 \%$ of UN countries included in the final analysis. Another selection bias may have resulted from the inclusion of only one set of answers from each country. Our results therefore provide a generalized representation of results from each country and do not take into account responder variability within individual countries. The study design aimed to overcome this bias by selecting a sample of questionnaires completed by WICC and primary care institution members from each country, as they were considered to have the most extensive knowledge regarding the study questions. Diversity between different regions inside the same country was not assessed. The submission of more than one response from each country allowed the comparison of data and increased data accuracy. 
Comparison with scientific literature

Although surveys have previously been published regarding ICPC, this study included detailed data from 31 additional countries. This is of importance, as it increases knowledge regarding ICPC, the prevalence of other healthcare classifications used, and the details of their use.

Comments were provided by some participants in the open response question. Although these were not considered in the current study, they may be important in highlighting other aspects of ICPC use to be accounted for in forthcoming studies.

The third version of the ICPC is currently being prepared and changes in worldwide use of this classification may occur once it comes into practice. 1,4,14,15 $^{-1}$

Research/Clinical practice impact

This study may act as a starting point in the definition of strategies to increase ICPC use in the primary care setting. Among countries with primary care services, we identified a wide diversity in ICPC use, ranging from widespread use to none at all. Future studies should aim to determine whether the ICPC is available in every country and to define the reasons why countries do not use it in primary care.

A further obstacle to the implementation of ICPC is likely to be the requirement for a paid license. Furthermore, in countries lacking a well-established primary care health service, the absence of a specific healthcare classification is justifiable.

\section{Conclusion}

Although the response rate to the questionnaire in our study was low, we can conclude that ICPC use around the world is not widespread and that use of the classification differs considerably between countries. Additionally, the countries that did report use of the ICPC in primary care mostly described it being a non-mandatory standard. Despite being originally intended for secondary care, ICD-10 is the most widely used classification after ICPC.

The paid license required for ICPC use is likely to be an obstacle to widespread implementation and use.

\section{References}

1. Lamberts H, Okkes IM; WONCA. The International classification of primary care". 2nd edition. Oxford: Oxford University Press; 1998.

2. Weed LL. Medical records that guide and teach. N Engl J Med. 1968;278(11):593-600. PMID: 5637758 DOI: http://dx.doi. org/10.1056/NEJM196803142781105

3. Pinto D. O que classificar nos registos clínicos com a Classificação Internacional de Cuidados Primários? Rev Port Med Geral Fam. 2014;30(5):328-34. 
4. Klinkman M, Pinto D. Building the International Classification of Primary Care, version 3. Rev Port Med Geral Fam. 2014;30(6):356-8.

5. Marshall I. ICPC around the world (2003). WONCA News. July 2003. [updated 2012; cited 2014 Jun 20]. Available from: http://www.ph3c.org/4daction/w3_CatVisu/en/icpc-around-the-world--2003-html?wDoclD=134

6. Sparks BL, Gupta SK. Research in family medicine in developing countries. Ann Fam Med. 2004;2 Suppl 2:S55-9. DOI: http://dx.doi.org/10.1370/afm.192

7. Mudiyanse RM. Need to teach family medicine concepts even before establishing such practice in a country. Asia Pac Fam Med. 2014;13(1):1. DOI: http://dx.doi.org/10.1186/1447-056X-13-1

8. United Nations. Member States of the United Nations. [cited 2014, 15 Jun 15]. Available from: http://www.un.org/en/members/

9. Primary Health Care Classification consortium (PH3C). Members and contacts by countries. [cited 2014 Jun 15]. Available from: http://www.ph3c.org/4daction/w3_CatVisu/en/members-\&-contacts-by-countries-.html?wCatIDAdmin=1103

10. WONCA Global Family Doctor. Member Interest. [cited 2014 Jun 15]. Available from: http://www.globalfamilydoctor.com/ member.aspx

11. World Health Organization. History of the development of the ICD. [cited 2015 Nov 25]. Available from: http://www.who.int/ classifications/icd/en/HistoryOfICD.pdf

12. Sambo LG. Health systems and primary care in the African region. WHO. [cited 2015 Nov 15]. Available from: https://www. aho.afro.who.int/pt-pt/ahm/issue/14/editorial/health-systems-and-primary-health-care-african-region

13. Hays R, Pong LT, Leopando Z. Primary care in the Asia-Pacific region: challenges and solutions. Asia Pac Fam Med. 2012;11(1):8. DOI: http://dx.doi.org/10.1186/1447-056X-11-8

14. WONCA. ICPC - 3: Where have we come from and Where are we going? [cited 2015 Nov 15]. Available from: http://www. ph3c.org/PH3C/docs/27/000267/0000382.pdf

15. Soler JK. The International Classification of Primary Care: a success story. The World Book of Family Medicine - European Edition 2015. [cited 2015 Nov 15]. Available from: http://www.woncaeurope.org/sites/default/files/041\%20\%E2\%80\%93\%20 The\%20International\%20Classification\%20of\%20Primary\%20Care.pdf 